\title{
RANCANGAN ALGORITMA GENERATOR MODEL 3D UNTUK MEMBUAT OBJEK BERUPA CABAI
}

\author{
Omega Rimba Gemilang ${ }^{* 1)}$, M. Suyanto ${ }^{2)}$, Sukoco ${ }^{3)}$ \\ ${ }^{1,2,3)}$ Magister Teknik Informatika Universitas AMIKOM Yogyakarta \\ *1) omega.rimba@gmail.com, ${ }^{2)}$ yanto@amikom.ac.id, ${ }^{3)}$ pak_koco@yahoo.com
}

\begin{abstract}
Along later development of technology, 3D models are increasingly used almost in all circles and fields. With so a 3D model can be used as a medium of learning simulations and attractive arranged in such a way. Alongside the presence of $3 D$ applications that can be used both free and proprietary, animators develop Karyana expected to support the learning of interest.

The aim of this study as a learning medium and can be used as a computer program to create $3 D$ models. In accordance with the proper sequence of steps, the process of making the object will be greatly facilitated. And supported by using a script program is expected to create objects in large quantities can be easily and vary in shape and size but they can be modified by the animator. Generator 3D model is a solution to create objects in large quantities. $3 D$ models created as an instance is the object of the chili. Generator 3D model has been tested and is capable of forming a desired object.
\end{abstract}

Keywords-Algorithm, Python, Modeling, 3D Models, Generator

\section{PENDAHULUAN}

Model tiga dimensi (3D) merupakan suatu representasi yang disederhanakan dari beberapa objek nyata atau situasi fisik yang berfungsi tertentu, dan mungkin terbatas. Penggunaan teknologi semakin populer di dalam bidang pendidikan, visualisasi model 3D dapat digunakan untuk belajar dan mengajar, sehingga pelajar mampu memahami pelajaran yang diajarkan lebih cepat daripada di kelas biasa (Zulhisam \& Rias, 2012). Pembelajaran menggunakan visualisasi 3D mampu memberikan pemahaman dari sudut pandang yang berbeda (Yang et al, 2012). Visualisasi 3D menuntut kreatifitas dari seorang pengajar dalam memodelkan bahan ajarnya (de Heras Ciechomski et al, 2013), dan menjadi sangat terbantu dengan adanya perangkat lunak khusus untuk pemodelan 3D seperti 3DsMax, Blender3D, Silverlights dan lain sebagainya (Zulhisam \& Rias, 2012).

Agar dapat memperoleh sesuatu hasil yang baik, diperlukan urutan langkah-langkah proses yang logis (algoritma) dalam membuatnya, begitu pula dalam pembuatan model 3D dapat menggunakan acuan urutan langkah proses (Yang et al, 2012). Sebagai contoh dalam membuat sebuah pohon lengkap dengan daunnya dapat menggunakan algoritma kolonisasi ruang (Jin et al, 2012). Maupun dalam membuat simulasi 3D pada pembusukan buah, ada urutan langkah proses yang dilalui (Kider et al, 2011). Dengan melakukan urutan langkah proses secara tepat yang telah ditentukan, mampu menghasilkan suatu model 3D (Yang et al, 2012).

Dalam penelitian-penelitian sebelumnya, dalam membuat model 3D masih memanfaatkan algoritma yang telah ada dan memiliki bentuk serta ukuran yang sama namun berulang. Dalam penelitian yang dilakukan, akan merancang sebuah algoritma yang nantinya dapat digunakan untuk membuat model 3D dengan beragam (random) ukuran dan bentuk. Sebagai objek dalam penelitian ini adalah cabai, karena cabai memiliki bentuk dan ukuran yang beragam. Meskipun objek cabai berukuran kecil, untuk membuatnya dalam jumlah banyak dan memiliki bentuk ukuran yang berbeda memerlukan waktu yang tidak 
sebentar. Dengan menggunakan algoritma yang terbentuk dan dikombinasikan dengan script program, diharapkan dalam membuat objek 3D berupa cabai dalam jumlah banyak mampu dilakukan dalam sekali klik namun tetap dapat modifikasi oleh animator.

\section{Tujuan Penelitian}

Dalam penelitian ini, tujuan utamanya adalah : Menghasilkan algoritma untuk membuat objek 3D cabai. Dan menghasilkan generator model 3D berupa objek cabai dalam jumlah banyak dan memiliki bentuk yang berbeda.

\section{Batasan Penelitian}

Berikut merupakan batasan-batasan variabel penelitiannya:

Dalam penelitian ini generator model terhadap objek cabai. Sebagai objek penelitian adalah cabai rawit. Dalam jumlah banyak yang dimaksud adalah banyaknya objek cabai yang dibuat. Jumlah banyak minimal adalah 10 objek. Hasil akhir penelitian ini adalah algoritma generator model cabai. Generator model cabai masih sebatas model dan belum termasuk pemberian tekstur warna.

\section{TINJAUAN PUSTAKA}

Penelitian Yang et al, (2012), menyajikan simulasi system akuisisi angiografi rotasi untuk memfasilitasi perbaikan dan evaluasi algoritma rekontruksi. Simulasi X-ray angiografi coroner dikembangkan berdasarkan algoritma distance-driven projection.

Pada penelitian Longay et al, (2012), melakukan pengukuran kemampuan software TreeSketch untuk pemodelan pohon secara kompleks yang terlihat alami. Menurut analisis Steven Longay dan kawan-kawan, software TreeSketch mampu membuat model pohon yang kompleks sekalipun sesuai dengan pengaturan pemodel. Namun masih belum ada pemodelan untuk bunga dan buah dari model pohon tersebut.

Penelitian Kider et al, (2011), menyajikan simulasi penuaan secara biologis dan proses pembusukan pada buah apel, jeruk dan tomat akibat infeksi jamur dan bakteri. Sistem yang dibuat menggunakan $\mathrm{C}++$ tersebut belum meliputi faktor kalsium, buah teriris atau terluka, serta gangguan dari serangga maupun cacing.

Penelitian Smith et al, (2007), menyajikan simulasi pohon berdasarkan topologi (hubungan antara urutan pertumbuhan dan penempatan organ) dan waktu perkembangan setiap bagian sudah sesuai dengan pohon Fuji yang diamati. Colin Smith menyarankan untuk menambahkan pengaruh cahaya dalam pergerakan pertumbuhan pohon.

Penelitian Runions et al, (2007), menyajikan pemodelan pohon lengkap dengan pemberian daun menggunakan pendekatan parameter numerik dan atribut non-numerik. Dengan memanfaatkan algoritma kolonisasi ruang, Adam dkk mampu membuat model 3D pohon secara lengkap dengan daunnya.

Penelitian Prusinkiewicz, (2000), menyajikan simulasi beraneka ragam model tanaman dan ekosistem tanaman sebagai media pembelajaran. Przemyslaw Prusinkiewicz menyarankan untuk menggabungkan mekanisme genetik ke dalan model simulasi tanaman.

\section{Landasan Teori}

Objek adalah benda, hal dan sebagainya yang dijadikan sasaran untuk diteliti, diperhatikan dan sebagainya (Kamus Besar Bahasa Indonesia, 2016), yang terlihat atau nyata dan relative stabil dalam bentuk (Reference, 2016). Model adalah suatu representasi yang disederhanakan dari beberapa objek nyata atau situasi fisik yang berfungsi tertentu, dan mungkin terbatas (Woolfson, 1999). untuk menunjukkan konstruksi atau penampilan 
sesuatu (Reference, 2016). Ada beberapa aspek yang harus dipertimbangkan dalam membangun model obyek, aspek tersebut memberi kontribusi pada kualitas hasil akhir. Hal-hal tersebut meliputi (Wartmann, 2004) : teknik untuk mendapatkan atau membuat data yang mendeskripsikan obyek, tujuan dari model, tingkat kerumitan, kesesuaian dengan bentuk aslinya, serta kemudahan manipulasi model. Simulasi merupakan suatu teknik meniru operasi-operasi atau proses- proses yang terjadi dalam suatu sistem dengan bantuan perangkat komputer dan dilandasi oleh beberapa asumsi tertentu sehingga sistem tersebut bisa dipelajari secara ilmiah (Law, 1991). Simulasi merupakan metode pelatihan yang meragakan sesuatu dalam bentuk tiruan yang mirip dengan keadaan yang sesungguhnya(Kamus Besar Bahasa Indonesia, 2016).

Dalam teknik modeling 3D terkadang dihadapkan pada suatu pilihan yang mengharuskan seorang modeller menggunakan teknik tertentu karena mungkin hanya dengan teknik tersebut sebuah model dapat buat. Setiap modeller terkadang memiliki beda pandangan terhadap pendefinisian teknik modeling ini namun pada dasarnya adalah sama. Ada 4 teknik modeling 3D yang secara umum dapat digunakan dalam membuat sebuah model menggunakan aplikasi pemodelan 3D (Wartmann, 2004) : Teknik Primitive Modeling (Solid Geometry Modeling), Teknik Polygonal Modeling (Sculpt Modeling), Teknik NURBS Modeling (Curve Modeling), Procedural Modeling. Algoritma merupakan prosedur sistematis untuk memecahkan masalah matematis dalam langkah-langkah terbatas(Kamus Besar Bahasa Indonesia, 2016). Langkah-langkah di dalam algoritma harus logis, ini berarti hasil dan urutan langkah-langkah tersebut harus dapat ditentukan, benar atau salah. Langkah-langkah yang tidak benar dapat memberikan hasil yang salah. Algoritma harus mempunyai lima ciri penting (Knuth, 1997) :

i. Algoritma harus berhenti setelah mengerjakan sejumlah langkah. Suatu program yang tidak pernah berhenti adalah program yang berisi algoritma yang salah.

ii. Setiap langkah harus didefinisikan dengan tepat dan tidak berarti-dua (ambigu).

iii. Algoritma memiliki nol atau lebih masukan (input). Masukan adalah besaran yang diberikan kepada algoritma sebelum algoritma mulai bekerja.

iv. Algoritma mempunyai nol atau lebih keluaran (output). Keluaran ialah besaran yang memiliki hubungan dengan masukan.

v. Algoritma harus singkat (efektif). Setiap langkah harus sederhana sehingga dapat dikerjakan dalam sejumlah waktu yang masuk akal.

\section{METODE PENELITIAN}

Dalam penelitian ini, metode berdasar pada Research and Development (R\&D) (Hasibuan, 2007), adalah suatu penelitian dimana alat yang telah buat diujicobakan dan dilihat tingkat efektifannya. Dalam penelitian ini, keefektifan yang akan diukur adalah keefektifan dari data simulasi. Selanjutnya metode untuk mengumpulkan data dilakukan dengan cara eksperimen yaitu dengan melakukan proses modeling 3D. Proses dilakukan dengan metode vertex key relatif kemudian menghasilkan objek cabai. File tersebut dapat digunakan pada beberapa software editor 3D. Metode analisis data yang digunakan dalam penelitian ini adalah menentukan Blendfile Data Objects. Metode ini digunakan untuk menentukan banyaknya vertices, edge, loops dan polygons pada setiap model cabai yang terbentuk dan membandingkannya, serta membandingkan secara langsung. Alur penelitian yang dilakukan dapat dilihat pada Gambar 1. 


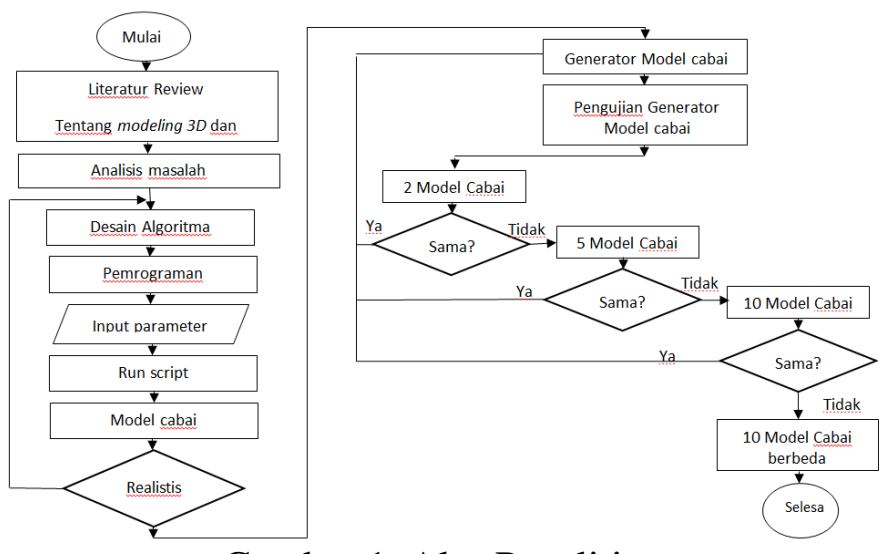

Gambar 1. Alur Penelitian

\subsection{Analisis dan Rancangan Sistem}

Dalam penelitian ini, analisis terdiri dari analisis masalah membuat model 3D yang menyerupai cabai. Dan dalam tahap perancangan sistem terdiri dari pembuatan alur pemodelan sehingga mampu membuat model cabai. Berikut merupakan penjabaran tiaptipa tahapannya.

\section{Analisis Data}

Dalam penelitian ini, analisis data dilakukan untuk mengetahui apa saja kendala saat merancang dan membuat generator model 3D berupa cabai. Serta untuk mengetahui pergerakan sumbu pusat dari vertex, edge dan face yang telah dikenakan proses extrude dan resize. Analisis data ini dilakukan dengan cara mengamati bentuk cabai nyata. Sebuah cabai memiliki 3 bagian yang menjadi satu. Bagian yang pertama adalah tangkai. Tangkai menyatukan antara buah cabai dengan batang. Bagian berikutnya yang berhubungan dengan tangkai adalah mahkota. Mahkota mempunyai tugas untuk memegang buah bacai. Dan bagian terakhir adalah buah cabai. Bagian-bagian cabai dapat dilihat pada Gambar 2.

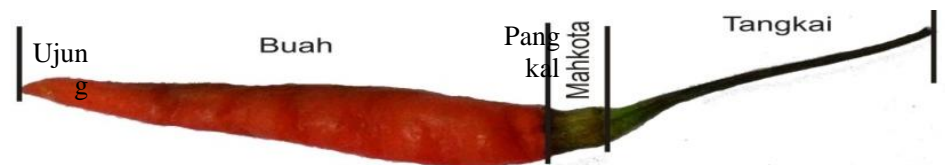

Gambar 2. Bagian-bagian cabai

Berikut contoh cabai yang digunakan dalam penelitian ini yang memiliki bentuk dan ukuran berbeda, ditunjukkan pada gambar 3.

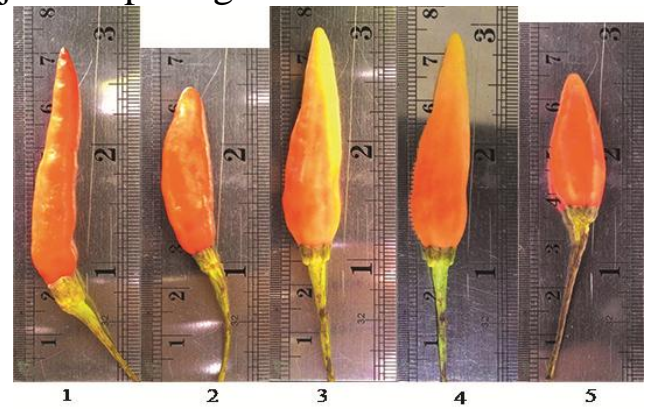

Gambar 3. Bentuk cabai (tampak depan, atas, kanan dan belakang)

Dari Gambar 3 objek cabai memiliki bentuk dan ukuran yang berbeda. Perbedaan terletak pada panjang tangkai, mahkota maupun buah, bentuk mahkota serta besar kecil buah cabai. Dari hasil pengukuran lima objek cabai diperoleh hasil pengukuran berdasarkan panjang dan diameter yang ditunjukkan pada Tabel 1 dan Tabel 2 : 
Tabel 1. Hasil pengukuran panjang objek cabai dalam millimeter (mm)

\begin{tabular}{|l|l|r|r|r|r|}
\hline No & $\begin{array}{c}\text { Keterangan } \\
(\mathrm{n})\end{array}$ & $\begin{array}{c}\text { Panjang } \\
\text { tangkai } \\
(\mathrm{t})\end{array}$ & $\begin{array}{c}\text { Panjang } \\
\text { mahkota } \\
(\mathrm{m})\end{array}$ & $\begin{array}{c}\text { Panjang } \\
\text { buah } \\
(\mathrm{b})\end{array}$ & $\begin{array}{c}\text { Panjang } \\
\text { keseluruhan } \\
(\mathrm{j})\end{array}$ \\
\hline 1 & Cabai 1 & 15 & 5 & 51 & 71 \\
\hline 2 & Cabai 2 & $21 \%$ & $7 \%$ & $72 \%$ & 63 \\
\hline 3 & Cabai 3 & $37 \%$ & $6 \%$ & $57 \%$ & 75 \\
\hline 4 & Cabai 4 & 24 & 4 & 47 & 74 \\
\hline 5 & Cabai 5 & $32 \%$ & $5 \%$ & $63 \%$ & 65 \\
\hline
\end{tabular}

Persentase dalam Tabel 1 diperoleh dari perbandingan antara panjang keseluruhan (tinggi tangkai, mahkota dan buah tanpa pengurangan atau penambahan pada sisi miring) dibanding dengan panjang tangkai, panjang mahkota dan panjang buah, sehingga dapat ditulis dengan rumus :

Persentase cabai $\mathrm{n}=\frac{t}{j} \times 100 \%$

Tabel 2. Hasil pengukuran diameter maksimal objek cabai dalam millimeter ( $\mathrm{mm}$ )

\begin{tabular}{|l|l|r|r|r|r|r|}
\hline No & $\begin{array}{c}\text { Keterangan } \\
(\mathrm{n})\end{array}$ & \multicolumn{2}{|c|}{$\begin{array}{c}\text { Diameter } \\
\text { tangkai }\left(\mathrm{d}_{1}\right)\end{array}$} & \multicolumn{2}{|c|}{$\begin{array}{c}\text { Diameter } \\
\text { mahkota }\left(\mathrm{d}_{2}\right)\end{array}$} & $\begin{array}{c}\text { Diameter buah } \\
\left(\mathrm{d}_{3}\right)\end{array}$ \\
\cline { 3 - 7 } & & Min & Mak & Min & Mak & \multicolumn{2}{c|}{ Mak } \\
\hline 1 & Cabai 1 & 1 & 3.5 & 5.5 & 7 & 9.5 \\
\hline 2 & Cabai 2 & 0.8 & 3 & 4.5 & 5 & 11 \\
\hline 3 & Cabai 3 & 1.2 & 4 & 5.5 & 6.5 & 11.5 \\
\hline 4 & Cabai 4 & 1 & 3.5 & 5.3 & 6.5 & 12 \\
\hline 5 & Cabai 5 & 1 & 3.5 & 5 & 7 & \\
\hline
\end{tabular}

Analisa berikutnya adalah menentukan bentuk dasar dari objek cabai. Dari pengamatan objek cabai dalam penelitian ini, bentuk dasar dari model cabai merupakan sebuah lingkaran, seperti yang ditunjukkan pada Gambar 4.

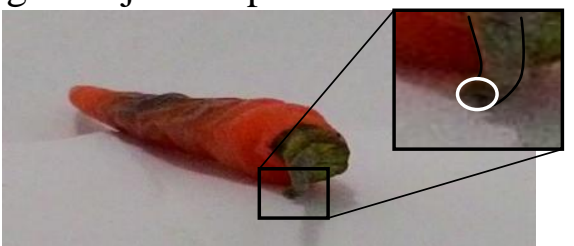

Gambar 4. Bentuk dasar / primitif dari model cabai

Pergerakan sumbu simetri dari sebuah cabai berbeda dengan cabai yang lain. Berikut merupakan pergerakan sumbu simetri dari salah satu cabai yang dijadikan contoh dalam penelitian ini.

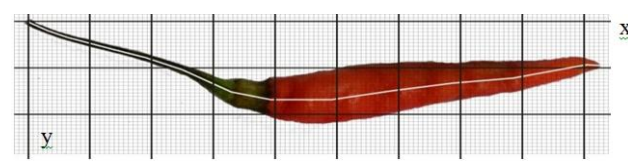

Gambar 5. Pergerakan sumbu simetri dari sebuah cabai

Untuk mengetahui pergerakan sumbu simetri dari sebuah cabai dengan cara meletakkan cabai pada diagram kartesian. Dari Gambar 5, pergerakan sumbu simetri dapat dilihat melalui garis tengah pada gambar cabai. Pergerakan sumbu simetri dari titik awal (pangkal) hingga akhir (ujung) sebuah cabai terhadap sumbu $x$ maupun terhadap sumbu $y$ 
bergerak sedikit demi sedikit. Pergerakan sumbu pusat inilah yang digunakan sebagai acuan untuk menentukan pergerakan pada pembuatan model 3D pada objek cabai.

\section{Rancangan Sistem}

Dari hasil analisis data, dalam merancang sebuah model cabai, dapat menggunakan mesh dasar berupa lingkaran (circle), ditunjukkan pada Gambar 6. Lingkaran yang terbentuk diberi proses extrude dan resize secara bergantian sehingga membentuk objek cabai.

a.

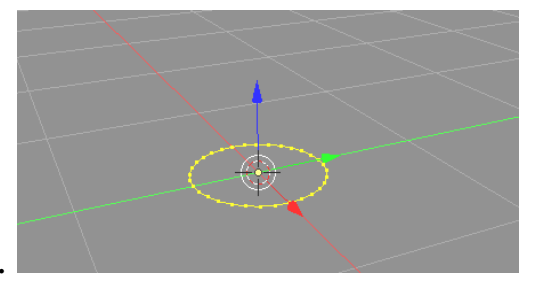

b.

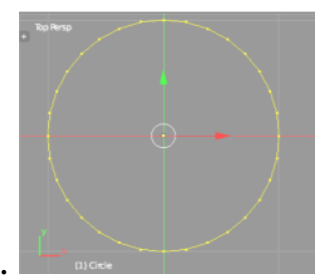

Gambar 6. Bentuk mesh dasar berupa lingkaran

a. tampak pengguna, dan b. tampak atas

Bentuk mesh dasar yang berupa lingkaran sempurna, pertama kali mengalami proses extrude untuk menambah lingkaran baru yang terhubung dengan lingkaran sebelumnya. Gambar 7 menunjukkan pergerakan proses extrude pertama terhadap sumbu (x, y, z) sebesar $(0,0.2,0.5)$ dan Gambar 8 menunjukkan pergerakan proses extrude kedua sebesar $(0.2,0.2,0.5)$. Pergerakan extrude terhadap sumbu (x, y, z) merupakan pergerakan titik pusat dari bentuk dasar, dalam penelitian ini adalah lingkaran. Untuk mendukung pembentukan generator model 3D berupa onjek cabai, dalam penelitian ini menggunakan script program python yang include pada aplikasi 3D Blender. Dalam menggunakan script, perintah tersebut dapat dituliskan :

1. bpy.ops.mesh.extrude_region_move (TRANSFORM_OT_translate $=\{$ "value $":(0,0.2,0.5)\})$

2. bpy.ops.mesh.extrude_region_move (TRANSFORM_OT_translate $=\{$ "value $":(0.2,0.2,0.5)\})$

Sehingga diprorel bentuk seperti pada Gambar 7 dan Gambar 8 berikut

a.

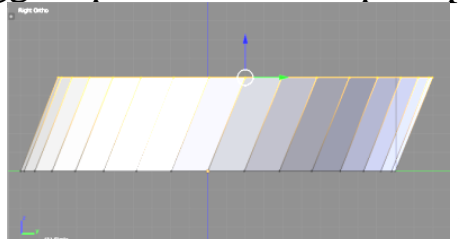

b.

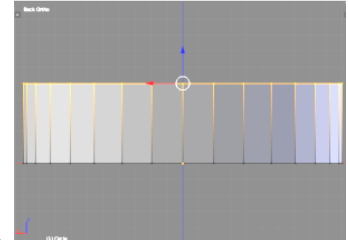

c.

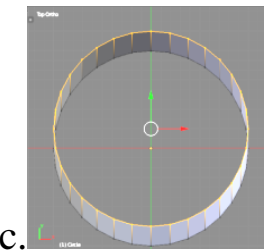

Gambar 7. Proses extrude pertama $(0,0.2,0.5)$

a. Tampak kanan, b. Tampak belakang, c. Tampak atas

Dari bentuk dasar berupa lingkaran, proses extrude mampu menghasilkan bentuk yang sama dengan bentuk awal, sehingga terbentuk sebuah tabung. Pada Gambar 7 merupakan hasil proses extrude satukali dengan ketinggian (bergeser keatas terhadap sumbu z) adalah 0.5 dan kemiringan terhadap sumbu $\mathrm{x}=0$ dan sumbu $\mathrm{y}=0.2$. Lingkaran awal dan lingkaran kedua terhubung dengan edge dan face.

a.

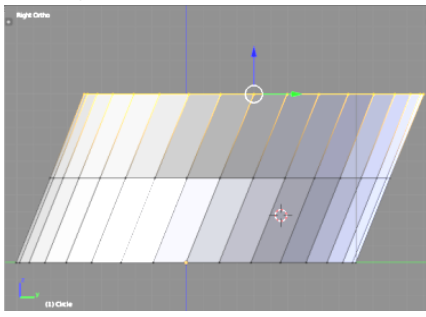

b.

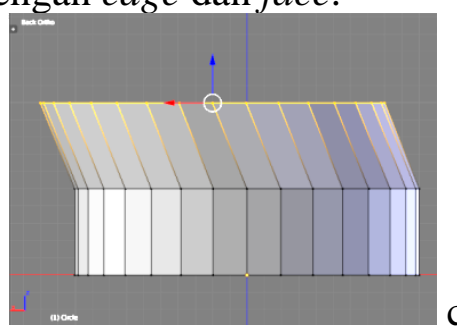

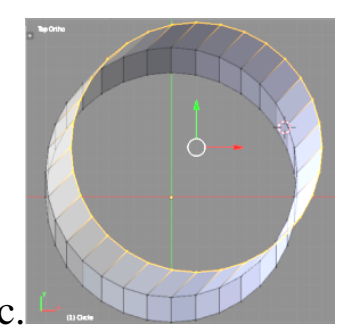

Gambar 8. Proses extrude kedua $(0.2,0.2,0.5)$

a. Tampak kanan, b. Tampak belakang, c. Tampak atas 
Pada Gambar 8 merupakan hasil dari proses extrude kedua yang diberikan dari bentuk dasar. Pada proses extrude kedua pergerakan sumbu pusat terhadap proses extrude pertama setinggi (bergeser keatas terhadap sumbu z ) 0.5 dan kemiringan terhadap sumbu $\mathrm{x}$ $=0.2$ dan sumbu $\mathrm{y}=0.2$.

Proses selanjutnya adalah resize, yang ditunjukkan pada Gambar 9, dan dalam menggunakan script, perintah resize dituliskan sebagai berikut :

\section{bpy.ops.transform.resize (value $=(1.4,1.4,1.4))$}

Script diatas akan menghasilkan perubahan ukuran yang merata/berbentuk lingkaran sempurna.

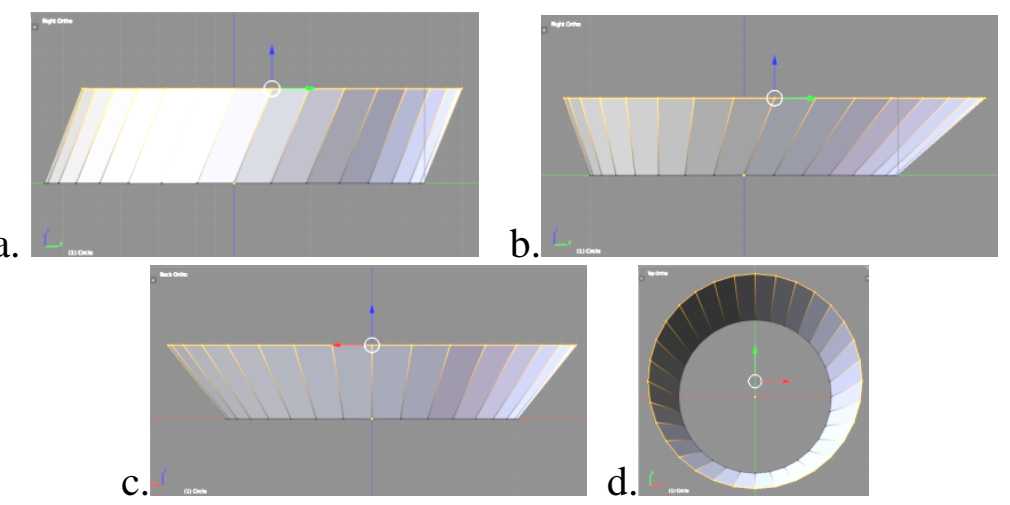

Gambar 9. Proses resize $(1.4,1.4,1.4)$ pertama

a. bentuk awal tampak kanan, b. tampak kanan,

c. tampak belakang, d. tampak atas

Proses resize yang ditunjukkan pada Gambar 9 merupakan kelanjutan dari proses extrude yang telah dilakukan sebelumnya. Proses resize tidak merubah posisi sumbu utama dari lingkaran hasil dari proses exturde, melainkan merubah ukurannya saja. Nilai yang diberikan pada proses resize terhadap sumbu (x, y, z) sebesar 1.4 berarti ukuran semula akan mengalami perubahan semakin besar sebanyak 0.4 .

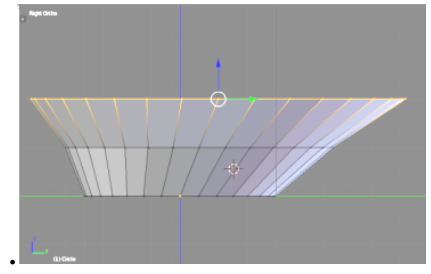

(a. tampak kanan)

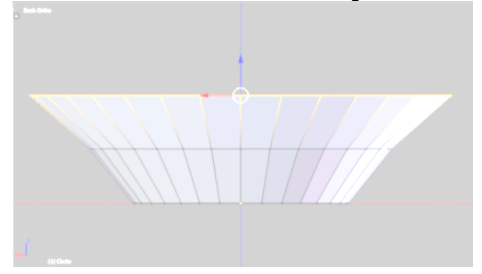

(b. tampak belakang)

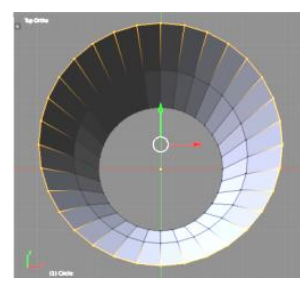

(c. tampak atas)

Gambar 10. Proses resize $(1.4,1.4,1.4)$ kedua

Dua proses resize yang ditunjukkan pada Gambar 9 dan Gambar 10 menghasilkan perubahan ukuran yang sempurna. Untuk menghasilkan perubahan dalam bentuk oval atau lonjong, maka nilai pada parameter $\mathrm{x}$ dan y dibuat berbeda, ditunjukkan pada script berikut bpy.ops.transform.resize (value $=(1 ., 1.4,1.4)$ )

Sehingga hasil resezi bentuk oval ditunjukkan pada gambar 11 berikut

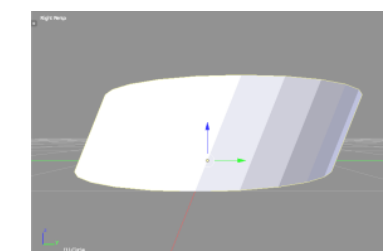

(a.bentuk tampak kanan)

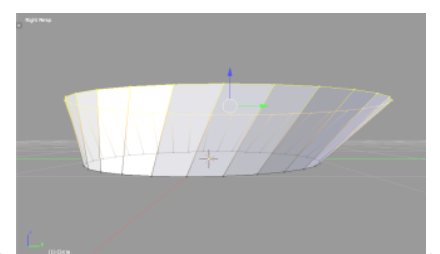

(b. hasil rezise tampak kanan) (c. tampak atas)

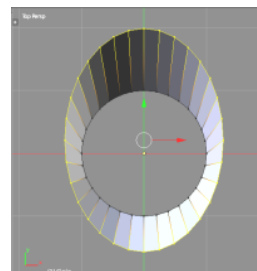

Gambar 11. Proses resize $(1,1.4,1.4)$ kedua 
Bentuk oval diperlukan dalam penelitian ini karena beberapa contoh objek cabai memiliki bentuk yang tidak rata.

\subsection{Perancangan Algoritma}

Dari hasil analisis data dan rancangan sistem yang telah dilakukan, dalam membentuk objek cabai dapat dilakukan berdasarkan urutan langkah sebagai berikut :

i. Masukkan rentang panjang cabai

ii. Masukkan rentang panjang tangkai

iii. Masukkan rentang panjang buah

iv. Membuat tangkai.

v. Membuat mahkota.

vi. Membuat buah cabai.

vii. Menampilkan objek cabai

Tahap awal dalam membuat model 3D berupa objek cabai adalah menentukan rentang atau kisaran panjang keseluruhan, panjang tangkai dan panjang buah. Dari sebuah bentuk dasar berupa lingkaran hingga terbentuk sebuah objek cabai, lingkaran yang merupakan bentuk dasar dari objek dalam penelitian ini diberi proses extrude dan resize secara bergantian sehingga lingkaran-lingkaran yang terbentuk saling terhubung dan tertutup oleh face. Langkah kedua adalah membuat tangkai, dari hasil analisa yang telah dilakukan, dalam tahap ini bentuk tangkai yang terbentuk diharapkan memiliki ukuran awal yang kecil dan ujung akhir semakin besar. Perbandingan ukuran lingkaran awal dengan ukuran lingkaran akhir pada tangkai sebesar rata-rata 1:3.5, sedangkan untuk panjang tangkai antara $21 \%$ hingga $52 \%$ dari panjang keseluruhan.

Tahap ketiga membuat mahkota, dalam membuat mahkota merupakan lanjutan dari langkah sebelumnya yaitu membuat tangkai. Diakhir proses membuat tangkai, dilakukan proses extrude dan resize yang berbeda, perbedaan ini terletak pada perubahan ukuran sekitar 3:5 dengan ukuran mahkota lebih besar dari ujung akhir pada tangkai. Pada mahkota juga memiliki perbedaan diameter lingkaran awal dan lingkaran akhir. Perbedaan ukuran lingkaran awal dan lingkaran akhir antara 4.5:7, sedangkan untuk panjang mahkota berkisar antara 5\% hingga 7\% dari panjang keseluruhan.

Tahap keempat atau terakhir adalah membuat buah. Pada buah, perbedaan ukuran diameter lingkaran bervariasi. Dikatakan bervariasi karena setiap bagian dari buah memiliki diameter yang berbeda. Diawali seukuran dengan ujung akhir mahkota, kemudian membesar dan setelah ukuran diameter maksimal, ukuran diameter berubah semakin mengecil hingga pada ujung. Sedangkan untuk panjang buah cabai sendiri berada pada kisaran panjang $43 \%$ hingga $72 \%$ dari panjang keseluruhan.

\subsection{Generator Model Cabai}

Generator model cabai terbentuk dari hasil pengembangan dan modifikasi dari script yang telah dibuat untuk menciptakan objek cabai. Dalam tahap ini penggunaan parameter secara acak sangat diperlukan guna menghasilkan objek cabai dalam jumlah banyak namun memiliki bentuk yang berbeda. Menggunakan masukan random namun terbatas mampu merubah sumbu pusat dari pergerakan proses extrude. Ada beberapa parameter yang diperlukan dalam membentuk objek cabai dalam jumlah banyak, antara lain :

1. Parameter rentang panjang cabai, parameter ini digunakan untuk menentukan panjang objek cabai yang akan dibuat. Inputan yang diberikan merupakan panjang minimum dan maksimum dari sejumlah objek yang akan dibentuk. 
2. Parameter rentang panjang tangkai, parameter ini digunakan untuk menentukan panjang tangkai yang akan dibuat. Inputan yang diberikan merupakan panjang minimum dan maksimum dari sejumlah tangkai yang akan dibentuk.

3. Parameter rentang panjang buah, parameter ini digunakan untuk menentukan panjang buah yang akan dibuat. Inputan yang diberikan merupakan panjang minimum dan maksimum dari sejumlah buah yang akan dibentuk.

4. Parameter extrude, parameter ini digunakan untuk merubah koordinat pusat hasil pemberlakuan extrude pada objek ede atau lingkaran terhadap sumbu $x$ dan $y$. Perubahan nilai parameter extrude pada sumbu $x$ dan $y$ dibatasi antara -20 hingga 20 satuan dibuat secara random oleh sistem dan dikalikan dengan nilai yang telah ditentukan.

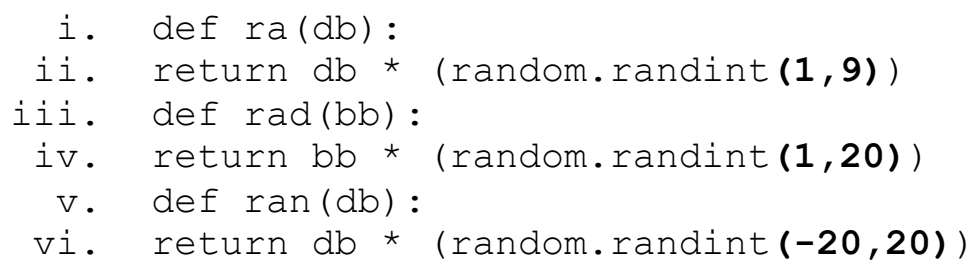

5. Parameter jumlah, perameter ini digunakan untuk menentukan berapa banyak objek cabai yang akan dibuat. Penentuan parameter jumlah dilakukan secara manual, yaitu animator memasukkan jumlah yang diinginkan.

for $\mathrm{i}$ in range(1): generator ()

6. Parameter posisi, parameter ini digunakan untuk meletakkan objek cabai secara tersebar agar lebih mudah dalam membandingkannya. Posisi penempatan objek cabai berdasarkan sumbu kuadrat kartesian terhadap sumbu $x$ dan $y$ secara acak dibatasi antara -20 hingga 20 satuan dibuat secara random oleh sistem.

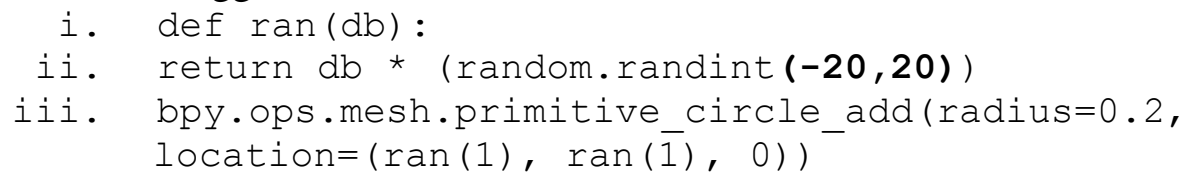

Untuk mempermudah dalam mengarahkan pergerakan sumbu simetri dari objek cabai, perlu penyederhanaan pada script model cabai, yang telah terbentuk. Penyederhanaan yang dilakukan dengan membentuk sebuah fungsi dengan kata kunci def pada script yang sama. Sebagai contoh pada baris 9-20 pada script diatas dapat disederhanakan menjadi :

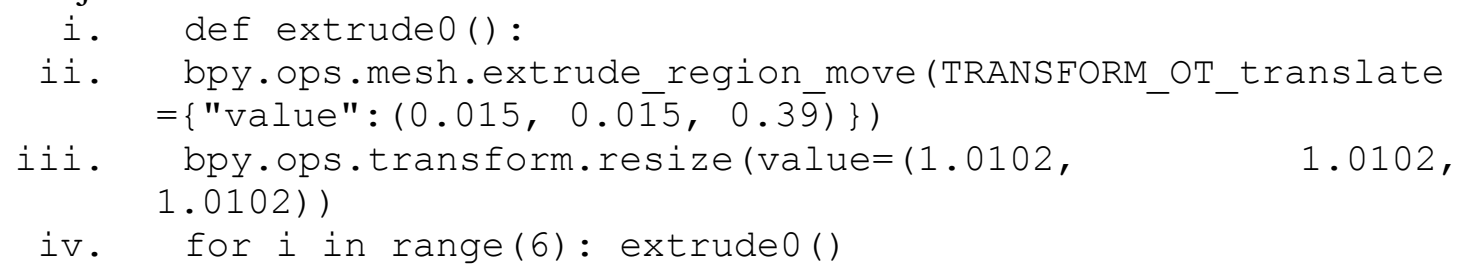

Untuk menjalankan proses extrude dan resize dari hasil penyederhanaan, cukup menjalankan perintah no. 4 dari script diatas dengan memanggil nama fungsinya. Dari urutan langkah yang telah dibentuk untuk membuat objek cabai, sehingga didapat sebuah pseudocode generator model sebagai berikut :

i. Menentukan banyak objek

ii. Membuat lingkaran dan menutup bagian pangkal

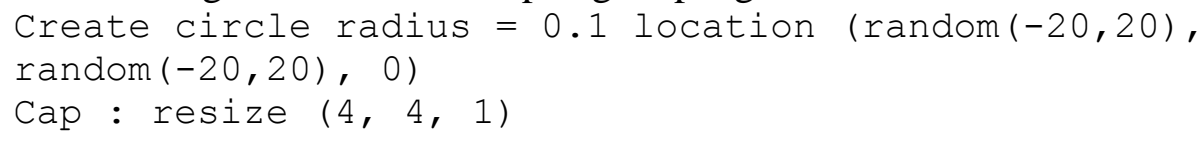


iii. Membuat tangkai

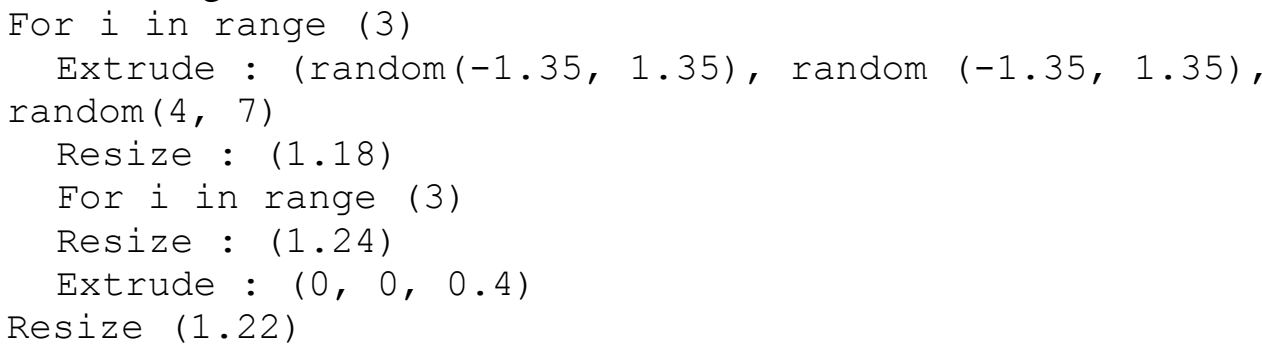

iv. Membuat mahkota

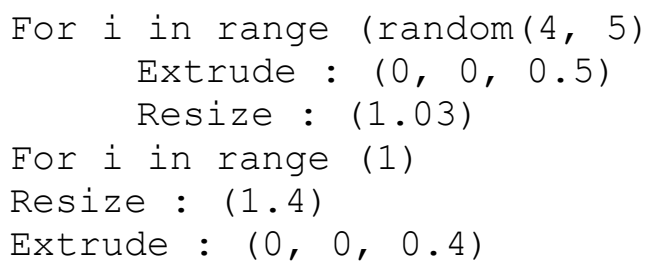

v. Membuat buah

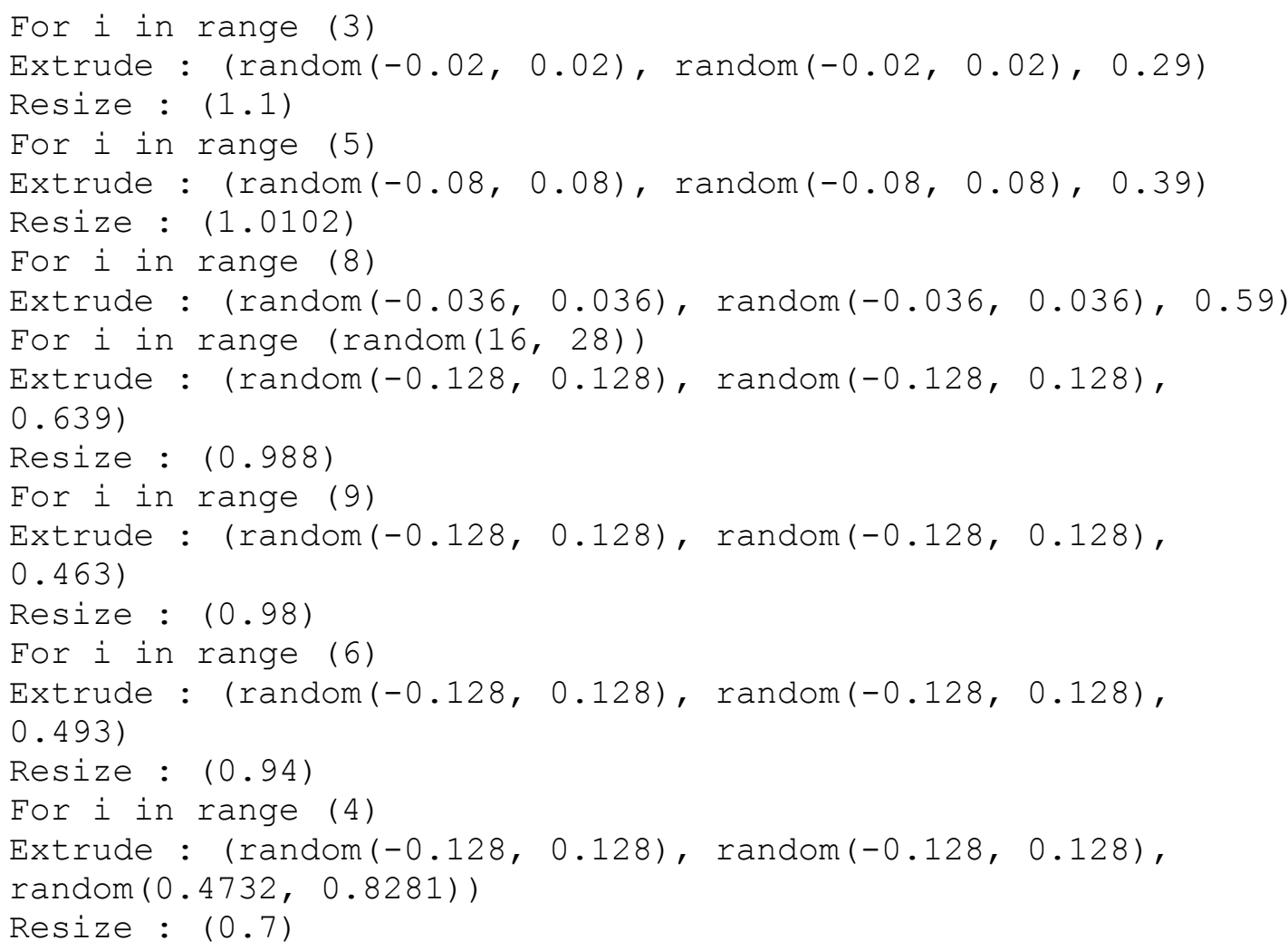

vi. Menghaluskan objek

Smooth

Dalam ujicoba generator cabai, sebanyak 2, 5 dan 10 objek cabai mampu menciptakan dalam sekali proses dengan bentuk yang berbeda, baik secara ukuran maupun panjang dari objek cabai. Hasil ujicoba generator model cabai dapat ditunjukkan pada Gambar 12 


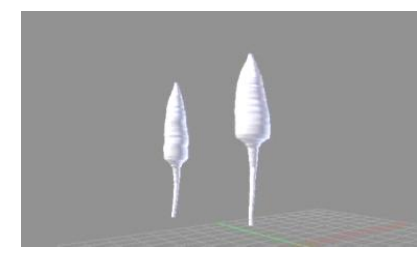

(a)

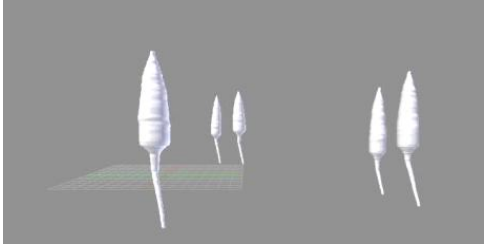

(b)

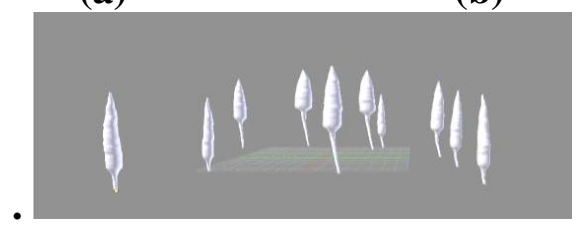

(c)

Gambar 12. Hasil Generator model cabai

\section{HASIL DAN PEMBAHASAN}

Dalam penelitian ini, pengolahan data dilakukan dengan membandingkan banyaknya vertices, edges, loops dan polygons pada objek cabai yang terbentuk dari generator cabai serta pendapat dari para pakar. Berikut data objek yang dihasilkan dari generator model cabai 2, 5 dan 10 ditunjukkan pada Gambar 13, Gambar 14 dan Gambar 15

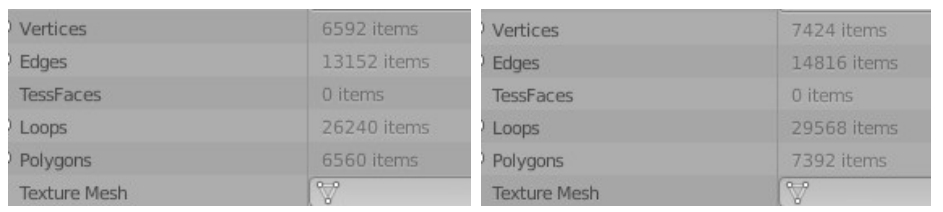

Gambar 13. Data objek dari generator model cabai sebanyak 2

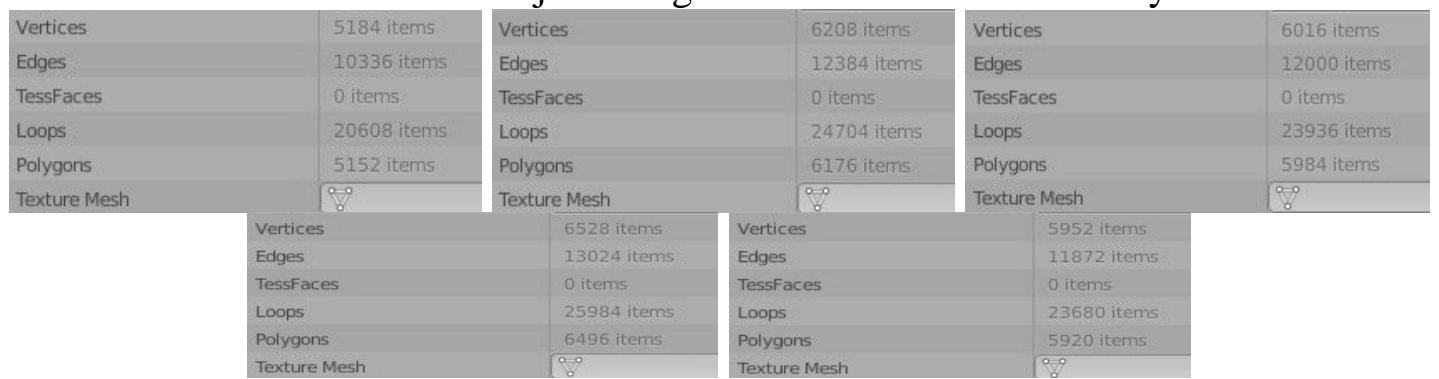

Gambar 14. Data objek dari generator model cabai sebanyak 5

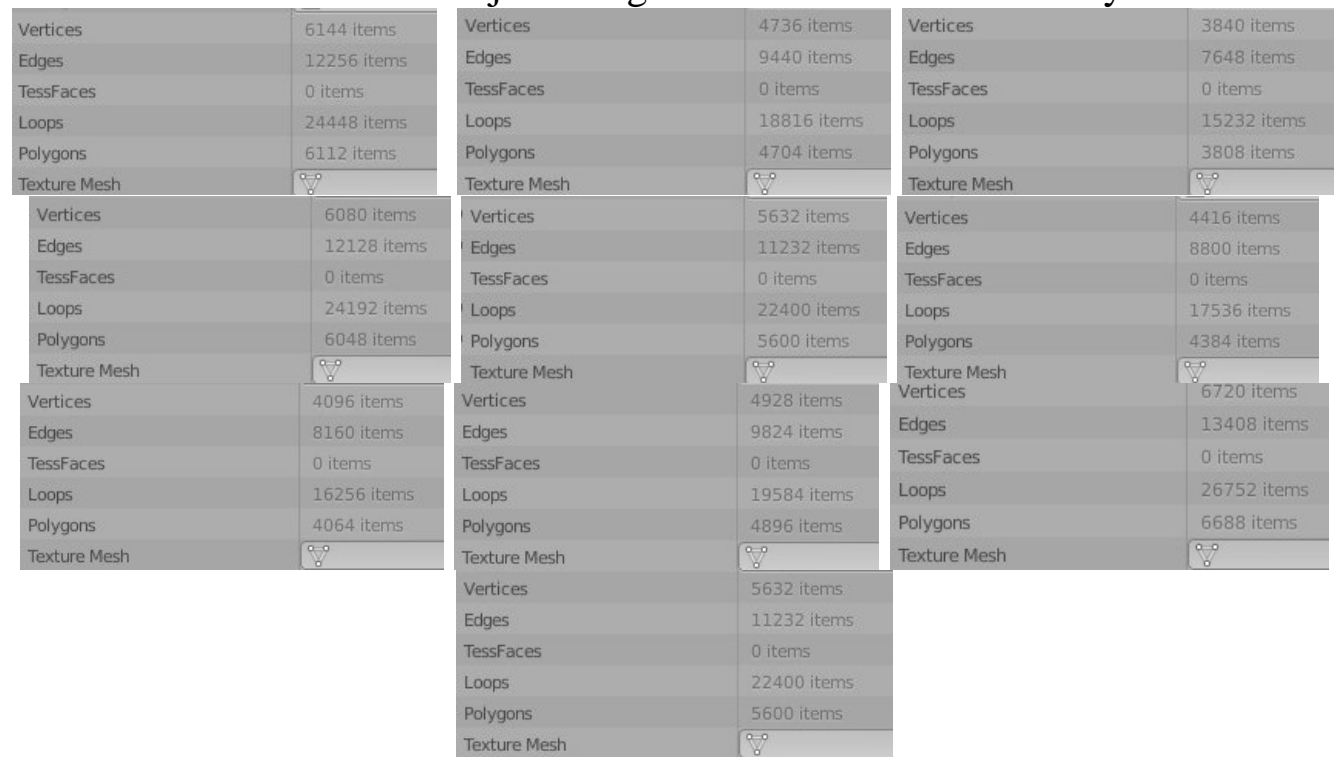

Gambar 15. Data objek dari generator model cabai sebanyak 10 
Dari hasil objek yang terbentuk oleh generator model cabai diperoleh vertices, edges, loops dan polygons yang beragam. Vertices merupakan banyaknya vertex yang terbentuk dalam membuat sebuah objek cabai. Edges merupakan banyaknya egde yang terhubung antara vertex. Loops merupakan banyaknya persimpangan yang terbentuk dari terbentuknya edges. Polygons merupakan banyaknya face yang terbentuk dari sebuah objek.

Tabel 3. Data objek

\begin{tabular}{|c|c|r|r|r|r|}
\hline No & Model Cabai & Vertices & \multicolumn{1}{c|}{ Edges } & \multicolumn{1}{c|}{ Loops } & \multicolumn{1}{c|}{ Polygons } \\
\hline 1 & Circle & 6592 & 13152 & 26240 & 6560 \\
\hline 2 & Circle.001 & 7424 & 14816 & 29568 & 7392 \\
\hline 3 & Circle.002 & 5184 & 10336 & 20608 & 5152 \\
\hline 4 & Circle.003 & 6208 & 12384 & 24704 & 6176 \\
\hline 5 & Circle.004 & 6016 & 12000 & 23936 & 5984 \\
\hline
\end{tabular}

Tabel 3. Data objek (lanjutan)

\begin{tabular}{|c|c|r|r|r|r|}
\hline No & Model Cabai & \multicolumn{1}{c|}{ Vertices } & \multicolumn{1}{c|}{ Edges } & \multicolumn{1}{c|}{ Loops } & \multicolumn{1}{c|}{ Polygons } \\
\hline 6 & Circle.005 & 6528 & 13024 & 25984 & 6496 \\
\hline 7 & Circle.006 & 5952 & 11872 & 23680 & 5920 \\
\hline 8 & Circle.007 & 6144 & 12256 & 24448 & 6112 \\
\hline 9 & Circle.008 & 4736 & 9440 & 18816 & 4704 \\
\hline 10 & Circle.009 & 3804 & 7648 & 15232 & 3808 \\
\hline 11 & Circle.010 & 6080 & 12128 & 24192 & 6048 \\
\hline 12 & Circle.011 & 5632 & 11232 & 22400 & 5600 \\
\hline 13 & Circle.012 & 4416 & 8800 & 17536 & 4384 \\
\hline 14 & Circle.013 & 4096 & 8160 & 16256 & 4064 \\
\hline 15 & Circle.014 & 4928 & 9824 & 19584 & 4896 \\
\hline 16 & Circle.015 & 6720 & 13408 & 26752 & 6688 \\
\hline 17 & Circle.016 & 5632 & 11232 & 22400 & 5600 \\
\hline
\end{tabular}

Tabel 3 menunjukkan banyaknya vertices, edge, loops dan polygons dari setiap objek cabai. Nilai yang terbentuk dari proses generator model cabai ini dapat digunakan sebagai salah satu pembanding yang digunakan dalam membedakan setiap objek cabai.

Dari hasil kuesioner yang telah peneliti berikan kepada pakar modeling dan simulasi di MSV Picture, pakar berpendapat generator model cabai yang telah dibuat mampu membuat objek cabai sejumlah yang diinginkan dan telah memiliki bentuk dan ukuran yang beragam. Pendapat dari pakar secara keseluruhan dapat dilihat pada Tabel 4 .

Tabel 4. Hasil kuesioner pakar modeling

\begin{tabular}{|l|l|c|c|c|c|}
\hline \multirow{2}{*}{ No } & \multicolumn{1}{|c|}{ Pertanyaan } & \multicolumn{3}{|c|}{ Jawaban } \\
\cline { 3 - 6 } & $\begin{array}{c}\text { Sangat } \\
\text { setuju }\end{array}$ & Setuju & $\begin{array}{c}\text { Kurang } \\
\text { yakin } \\
\text { setuju }\end{array}$ & $\begin{array}{c}\text { Tidak } \\
\text { setuju }\end{array}$ \\
\hline 1 & $\begin{array}{l}\text { Generator model cabai mampu membuat objek } \\
\text { cabai }\end{array}$ & 3 & 4 & - & - \\
\hline 2 & $\begin{array}{l}\text { Objek yang terbentuk sudah menyerupai bentuk } \\
\text { aslinya (realistis) }\end{array}$ & 1 & 5 & 1 & - \\
\hline 3 & $\begin{array}{l}\text { Generator mampu membuat objek dalam jumlah } \\
\text { banyak (lebih dari 5) dalam sekali proses }\end{array}$ & 5 & 2 & - & - \\
\hline 4 & $\begin{array}{l}\text { Objek cabai yang terbentuk memiliki bentuk dan } \\
\text { ukuran yang berbeda }\end{array}$ & 3 & 3 & 1 & - \\
\hline 5 & $\begin{array}{l}\text { Apa pendapat anda mengenai generator model cabai : } \\
\text { Rata-rata responden menjawab : "sudah bagus dan memadai" }\end{array}$ \\
\hline
\end{tabular}


Dalam penelitian ini, tahapan analisis hasih merupakan proses pengujian kesamaan dari proses generator model cabai dan pendapat pakar modeling. Dari hasil pengamatan pengolahan data terhadap generator middel cabai, setiap objek cabai yang terbentuk memiliki jumlah vertices, edge, loops dan polygons yang berbeda. Namun masih terdapat objek cabai yang memiliki jumlah vertices, edge, loops dan polygons sama dengan objek yang lain, ditunjukkan pada Tabel 3 objek cabai Circle.011 dan Circle.016. Data objek yang terbentuk menandakan secara data dua objek cabai tersebut sama, namun secara bentuk berbeda. Perbedaan kedua objek tersebut dapat diamati pada Gambar 17.

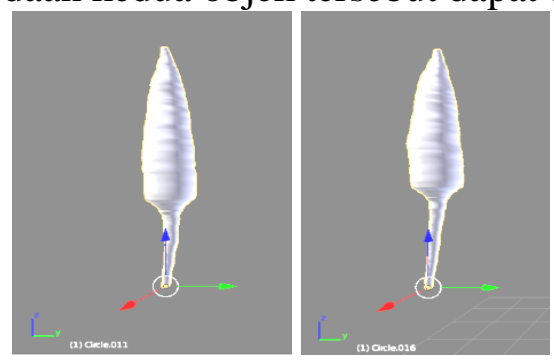

Gambar 17. Objek cabai Circle.011 dan objek cabai Circle.016

Sehingga secara keseluruhan generator model cabai mampu membentuk banyak objek cabai dengan beragam bentuk yang berbeda secara bentuk ukuran dan data objek berupa vertices, edges, loops dan polygons .

Didukung oleh pendapat pakar modeling dan simulasi dalam kuesioner yang telah diberikan, pakar modeling dan simulasi berpendapat objek cabai yang dihasilkan dari Generator Model Cabai sudah menyerupai bentuk aslinya (realistis) dan memiliki bentuk dan ukuran yang berbeda.

\section{KESIMPULAN DAN SARAN}

\subsection{Kesimpulan}

Berdasarkan beberapa penerapan dan pengujian sebelumnya serta pendapat pakar modeling dan simulasi, maka dapat disimpulkan seperti berikut ini.

1. Telah dibuat algoritma untuk membuat model cabai, yang dengannya dapat dibuat banyak cabai secara otomatis. Urutan membuat model cabai dimulai dengan membuat circle, memberi penutup pada circle, mengextrude dan resize secara bergantian untuk membentuk model cabai.

2. Generator model cabai yang terbentuk mampu menghasilkan objek cabai dalam jumlah banyak sesuai keingingan dan memiliki bentuk yang berbeda satu dengan yang lain.

\subsection{Saran}

Dalam penelitian ini terdapat beberapa kemungkinan yang dapat digali lebih lanjut oleh peneliti selanjutnya, berikut merupakan beberapa saran yang dapat menjadi pertimbangan peneliti selanjutnya.

1. Dalam penelitian selanjutnya dapat memasukkan parameter rotasi pada pembentukan model.

2. Mengembangkan model hasil generator tidak hanya model cabai, melainkan bentuk yang lain seperti wortel tanpa daun, singkong, dan lain sebagainya

3. Penambahan tekstur pada model akan membuat model yang dibentuk lebih menyerupai bentuk aslinya. 


\section{DAFTAR PUSTAKA}

Averill M. Law, W. D. (1991). Simulation Modeling and Analysis. 2nd ed. New York : McGraw-Hill Inc.

de Heras Ciechomski, P., Klann, M., Mange, R., \& Koeppl, H. (2013). From biochemical reaction networks to 3D dynamics in the cell: The ZigCell3D modeling, simulation and visualisation framework. In Biological Data Visualization (BioVis), 2013 Symposium on, (pp. 41-48). IEEE.

Hasibuan, Zainal A., (2007), Metode penelitian pada Bidang Ilmu Komputer Dan Teknologi Informasi : Konsep, Teknik dan Aplikasi, Jakarta : Fakultas Ilmu Komputer Universitas Indonesia.

Jin, L. W., Zhang, Q., Lei, B., \& Li, Z. Y. (2012). Simulation and research on 3D gouging model based on Abaqus/Explicit. In Electromagnetic Launch Technology (EML), 2012 16th International Symposium on (pp. 1-5), IEEE.

Kamus Besar Bahasa Indonesia, 18 September 2016, http://kbbi.web.id/simulasi

Kider, J. T., Raja, S., \& Badler, N. I. (2011). Fruit senescence and decay simulation. In Computer Graphics Forum, Vol. 30, No. 2, Blackwell Publishing Ltd, 257-266.

Knuth, Donald Ervin, (1997), The Art Of Computer Programming 3rd edition, Canada : Addison Wesley Longman.

Longay, S., Runions, A., Boudon, F., \& Prusinkiewicz, P. (2012). Treesketch: interactive procedural modeling of trees on a tablet. In Proceedings of the international symposium on sketch-based interfaces and modeling, Eurographics Association, 107-120.

Prusinkiewicz, P. (2000). Simulation modeling of plants and plant ecosystems. Communications of the ACM, 43(7), 84-93.

Reference, 18 September 2016, http://dictionary.reference.com/browse/modeling?s=t

Smith, C., Godin, C., Guédon, Y., Prusinkiewicz, P., \& Costes, E. (2007). Simulation of apple tree development using mixed statistical and biomechanical models. In 5th International Workshop on Functional-Structural Plant Models, (pp. 31-1).

Wartmann, Carsten. (2004). Panduan Lengkap Menggunakan Blender. Jakarta : Elex Media Komputindo.

Woolfson, M. M. and Pert, G. J., (1999), An Introduction to Computer Simulation., New York : Oxford University Press.

Yang, G., Hu, Y., Huang, X., Shu, H., \& Toumoulin, C. (2012). Simulation environment of $\mathrm{X}$-ray rotational angiography using $3 \mathrm{D}+\mathrm{t}$ coronary tree model. In Engineering in Medicine and Biology Society (EMBC), 2012 Annual International Conference of the IEEE (pp. 629-632). IEEE.

Zulhisam, M., \& Rias, R. M. (2012, February). Modeling Binary Tree Algorithm in 3-D Interactive Visualization: A Prototype. In Intelligent Systems, Modelling and Simulation (ISMS), 2012 Third International Conference on (pp. 525-528). IEEE. 